\title{
Hydropriming Increases Germination of Lentil (Lens culinaris Medik.) under Water Stress
}

\author{
Sevil SAĞLAM ${ }^{1)}$, Sibel DAY' ${ }^{1)}$, Gamze KAYA ${ }^{2)}$, Ayşegül GÜRBÜZ2) \\ ${ }^{1)}$ University of Ankara, Faculty of Agriculture, Department of Field Crops, Turkey; siday957@hotmail.com \\ ${ }^{2)}$ Central Research Institute for Field Crop, PK 226 Ulus-Ankara, Turkey; pascalcik@hotmail.com (corresponding author)
}

\begin{abstract}
Fresh seeds of lentil cultivars 'Pul 11', 'Sultan 1' and 'Meyveci 2001' were subjected to hydropriming with an objective to improve germination and seedling vigor under water stress induced by PEG- 6000 at the water potentials of 0.0 (distilled water), $-0.3 \mathrm{and}-0.6 \mathrm{MPa}$. Results revealed that germination delayed in increasing water stress with variable germination among cultivars. Root, shoot length and germination were higher but mean germination time were lower in the primed seeds. Seeds were able to germinate at all concentrations of PEG but higher germination and improved seedling growth was observed in primed seeds. Cultivars showed variable response to water stress and cv. 'Pul 11' with the lightest seed weight gave better performance. Whereas, cv. 'Sultan 1' enhanced germination percentage with hydropriming under increased water stress. It was concluded that inhibition of germination due to water stress should be overcome by using primed lentil seeds.
\end{abstract}

Keywords: lentil, hydropriming, water stress, germination, seedling growth

\section{Introduction}

Lentil (Lens culinaris Medik.) is cultivated extensively in rainfed areas of Turkey. It is grown in many countries of the Mediterranean region as a cheap source of protein. It is considered as relatively tolerant to drought (Muehlbauer et al., 1985). It is widespread in areas having a mild and warm climate; as relatively high or low temperatures are the most important limiting factors in its cultivation.

Lack of adequate soil moisture in the seedbed is a major obstacle to the establishment of lentil crop, because inadequate soil moisture can reduce germination, slow down seedling growth and decrease yield in rainfed crops (Sharma and Prasad, 1984). One of the most important effects of drought is the failure to establish plant stand; which consequently results in reduction of growth and yield. Most commonly the seeds are occasionally sown in seedbeds having unfavorable moisture because of the lack of rainfall at sowing time (Angadi and Entz, 2002), which results poor and unsynchronized seedling emergence (Mwale et al., 2003). Under the conditions of central Anatolia in Turkey, where the moisture content of soil at sowing time (from mid-April to mid-May) is most often not adequate, presentimg significant variation in micro pockets of the same field, drought results irregular seed germination and stand establishment.

Rapid seed germination along with fast germination and seedling emergence substantially contribute to high lentil yield under drought conditions. Seed priming has been successfully demonstrated to improve germination and emergence in seeds of many crops, particularly those of vegetables and small seed grasses (Heydecker and Coolbaer, 1977; Bradford, 1986). The beneficial effects of priming have also been demonstrated for many field crops like wheat, sugar beet, maize, soybean and sunflower (Parera and Cantliffe, 1994; Singh, 1995; Khajeh-Hosseini et al., 2003; Sadeghian and Yavari, 2004). Ghassemi-Golezani et al. (2008) has reported beneficial effects of hydropriming on germination and field emergence of lentil but no report shows the performance of hydropriming under water stress. The study aimed to examine the possibilities of overcoming water stress during germination by hydropriming in lentil.

\section{Materials and methods}

Seeds of popular Turkish lentil cv. 'Pul 11', 'Meyveci 2001' and 'Sultan 1', used in the study were obtained from the Central Field Crops Research Institute, Ankara, Turkey. These cultivars have mean one hundred seed weights of $63.4 \mathrm{~g}, 68.6 \mathrm{~g}$ and $70.7 \mathrm{~g}$ respectively. Water stresses at osmotic potentials of -0.3 and $-0.6 \mathrm{MPa}$ were adjusted using PEG-6000 (Polyethylene glycol $6000 \mathrm{mw}$ ) according to Michel and Kaufmann (1973) before the start of the experiment. Distilled water served as control (0.0 MPa).

\section{Hydropriming}

For hydropriming, seeds of lentil cultivars were immersed in distilled water at $20^{\circ} \mathrm{C}$ for $12 \mathrm{~h}$ under dark conditions (Ghassemi-Golezanik et al., 2008). Thereafter, the treated seeds were surface-dried and left to their original 
104

moisture content at room temperature $\left(22 \pm 1^{\circ} \mathrm{C}, 45 \%\right.$ relative humidity) determined by changes in seed weight.

Moisture content of untreated seeds (unprimed) and hydroprimed seeds were equilibrated at room temperature during 2 days.

\section{Germination tests}

Four replicates of 50 seeds $(50 \times 4=200$ seeds $)$ were germinated between three layered rolled filter paper with 30 $\mathrm{ml}$ of respective test solutions. The rolled paper with seeds was put into sealed transparent plastic bags to avoid moisture loss. Seeds were allowed to germinate at $20 \pm 1^{\circ} \mathrm{C}$ in dark for 10 days. A seed was considered germinated when the emerging radicle elongated to $2 \mathrm{~mm}$. Germination percentage was recorded every $24 \mathrm{~h}$ mean germination time (MGT) was calculated for the rate of germination (Ellis and Roberts, 1980) using the following formula:

$\mathrm{MGT}=\sum(\mathrm{Dn}) / \sum \mathrm{n}$, where $\mathrm{n}$, is the number of seeds which germinate on day $\mathrm{D}$ and $\mathrm{D}$ being the number of days counted from the beginning of germination test. Root length, shoot length and seedling fresh and dry weights were measured after the 10 th day. Dry weights were measured after drying samples at $70^{\circ} \mathrm{C}$ for $48 \mathrm{~h}$ in an air oven.

\section{Experimental design}

The experimental design was three factors factorial (seed treatment $\times$ cultivar $\times$ water stress) arranged in a completely randomized design with four replicates. The first factor was the seed treatments (unprimed and hydroprimed), the second being the cultivars ('Pul 11', 'Meyveci 2001' and 'Sultan 1') and the third represented by different water stress levels $(0.0,-0.3$, and-0.6 $\mathrm{MPa})$. Data for germination percentage were subjected to arcsine transformation before analysis of variance using MSTAT-C program (Michigan State University). The differences between the means were compared by LSD values $(\mathrm{P}<0.05)$.

\section{Results and discussions}

Main effects of hydropriming and water stress on germination percentage (GP), mean germination time (MGT), root length (RL), shoot length (SL) seedling fresh weight (SFW) and seedling dry weight (SDW) of the cultivars are shown in (Tab. 1). Higher germination percentage was obtained from primed seeds compared to control seeds. Hydropriming showed $90 \%$ germination under water stresses, but germination percentage drastically declined and delayed in unprimed seeds. Germination was severely limited to $70 \%$ at the highest water stress level of -0.6 MPa.

A three-way interaction was determined for GP, MGT, SL, SFW and SDW (Tab. 1). Considering cultivars, 'Sultan 1' gave higher germination percentage with $100 \%$ germination under all water stresses (Tab. 2). Unprimed seeds resulted in lower germination regardless of water stress. Mean germination time increased with an increase in water stress; however, hydropriming shortened it more compared to unprimed. The time to seed germination was

Tab. 1. Main effects and interactions of seed treatment, cultivar and water stress on germination and seedling growth of lentil cultivars

\begin{tabular}{|c|c|c|c|c|c|c|c|}
\hline Main effect & & $\begin{array}{c}\text { Germination } \\
\text { percentage }(\%)\end{array}$ & $\begin{array}{c}\text { Mean } \\
\text { germination } \\
\text { time (day) }\end{array}$ & $\begin{array}{c}\text { Shoot } \\
\text { length }(\mathrm{cm})\end{array}$ & $\begin{array}{c}\text { Root } \\
\text { length }(\mathrm{cm})\end{array}$ & $\begin{array}{c}\text { Seedling fresh } \\
\text { weight }\left(\text { mg plant }^{-1}\right)\end{array}$ & $\begin{array}{c}\text { Seedling dry } \\
\text { weight (mg } \\
\left.\text { plant }^{-1}\right)\end{array}$ \\
\hline \multirow{2}{*}{ Seed treatment } & Unprimed & $85^{b}$ & $4.25^{a}$ & $3.14^{b}$ & $3.01^{b}$ & $125^{b}$ & $9.3^{b}$ \\
\hline & Primed & $90^{\mathrm{a}}$ & $3.68^{b}$ & $7.11^{\mathrm{a}}$ & $7.14^{\mathrm{a}}$ & $158^{a}$ & $12.9^{\mathrm{a}}$ \\
\hline \multirow{3}{*}{ Cultivar } & 'Pul 11' & 86 & $3.53^{b}$ & $5.44^{a}$ & $5.81^{a}$ & $143^{b}$ & $11.8^{a}$ \\
\hline & 'Meyveci 2001' & 91 & $4.08^{a}$ & $4.49^{b}$ & $3.95^{b}$ & $124^{c}$ & $9.3^{b}$ \\
\hline & 'Sultan 1' & 86 & $4.27^{a}$ & $5.45^{a}$ & $5.45^{a}$ & $158^{a}$ & $12.3^{a}$ \\
\hline \multirow{3}{*}{$\begin{array}{l}\text { Water stress } \\
\qquad(\mathrm{MPa})\end{array}$} & 0.0 & $99^{a}$ & $1.68^{c}$ & $10.90^{\mathrm{a}}$ & $5.32^{b}$ & $313^{a}$ & $17.6^{a}$ \\
\hline & -0.3 & $94^{a}$ & $3.03^{b}$ & $3.77^{b}$ & $6.87^{a}$ & $90^{b}$ & $11.3^{b}$ \\
\hline & -0.6 & $70^{b}$ & $7.18^{a}$ & $0.70^{\mathrm{c}}$ & $3.03^{c}$ & $22^{c}$ & $4.4^{c}$ \\
\hline \multicolumn{8}{|c|}{ Summary of ANOVA } \\
\hline Treatment $(\mathrm{T})$ & & * & ** & ** & ** & ** & $* *$ \\
\hline Cultivar (C) & & NS & $* *$ & $* *$ & $* *$ & $* *$ & $* *$ \\
\hline Drought (D) & & $* *$ & $* *$ & ** & $* *$ & ** & $* *$ \\
\hline $\mathrm{T} \times \mathrm{C}$ & & NS & $* *$ & $*$ & * & $* *$ & $* *$ \\
\hline $\mathrm{T} \times \mathrm{D}$ & & NS & $* *$ & $* *$ & $* *$ & $* *$ & $* *$ \\
\hline $\mathrm{C} \times \mathrm{D}$ & & $* *$ & $* *$ & ** & $*$ & $* *$ & ** \\
\hline $\mathrm{T} \times \mathrm{C} \times \mathrm{D}$ & & $* *$ & $* *$ & ** & NS & ** & $*$ \\
\hline
\end{tabular}

${ }^{*}$ and ${ }^{* *}$ significant difference at $\mathrm{P}<0.05$ and $0.01 ; \mathrm{NS}$, not significant 
Tab. 2. Germination percentage (\%), mean germination time (MGT) (day) and shoot length (cm) of lentil cultivars exposed to hydropriming at various water stress levels

\begin{tabular}{|c|c|c|c|c|c|c|c|}
\hline \multirow{2}{*}{ Cultivar } & \multirow{2}{*}{ Water stress $(\mathrm{MPa})$} & \multicolumn{2}{|c|}{ Germination } & \multicolumn{2}{|c|}{ MGT } & \multicolumn{2}{|c|}{ Shoot length } \\
\hline & & Unprimed & Primed & Unprimed & Primed & Unprimed & Primed \\
\hline \multirow{3}{*}{ 'Pul 11' } & 0.0 & $97.0^{a}$ & $100.0^{a}$ & $1.48^{\mathrm{h}}$ & $1.81^{\mathrm{gh}}$ & $6.5^{c}$ & $15.5^{a}$ \\
\hline & -0.3 & $99.5^{\mathrm{a}}$ & $98.0^{\mathrm{a}}$ & $2.49^{\mathrm{fg}}$ & $2.94^{\mathrm{cf}}$ & $2.8^{\mathrm{f}}$ & $5.8^{\mathrm{cd}}$ \\
\hline & -0.6 & $51.5^{\mathrm{c}}$ & $73.0^{\mathrm{b}}$ & $6.91^{\mathrm{c}}$ & $5.57^{\mathrm{d}}$ & $0.3^{\mathrm{i}}$ & $1.7^{\text {fgh }}$ \\
\hline \multirow{3}{*}{ 'Meyveci 2001' } & 0.0 & $97.5^{a}$ & $99.5^{a}$ & $1.60^{\mathrm{h}}$ & $1.83^{\mathrm{gh}}$ & $9.0^{\mathrm{b}}$ & $15.0^{\mathrm{a}}$ \\
\hline & -0.3 & $99.5^{\mathrm{a}}$ & $96.0^{\mathrm{a}}$ & $3.38^{\mathrm{c}}$ & $3.08^{\mathrm{ef}}$ & $2.3^{\mathrm{fg}}$ & $5.1^{\mathrm{de}}$ \\
\hline & -0.6 & $50.3 c$ & $72.5^{b}$ & $9.91^{\mathrm{a}}$ & $5.83^{d}$ & $0.2^{\mathrm{i}}$ & $1.1^{\text {ghi }}$ \\
\hline \multirow{3}{*}{ 'Sultan 1' } & 0.0 & $98.5^{a}$ & $100.0^{a}$ & $1.44^{\mathrm{h}}$ & $1.94^{\mathrm{gh}}$ & $4.6^{\mathrm{dc}}$ & $14.9^{a}$ \\
\hline & -0.3 & $93.0^{a}$ & $100.0^{\mathrm{a}}$ & $2.89^{\mathrm{cf}}$ & $3.38 \mathrm{e}$ & $2.3^{\mathrm{fg}}$ & $4.3^{c}$ \\
\hline & -0.6 & $72.5^{b}$ & $100.0^{\mathrm{a}}$ & $8.15^{b}$ & $6.71^{\mathrm{c}}$ & $0.2^{\mathrm{i}}$ & $0.8^{\mathrm{hi}}$ \\
\hline
\end{tabular}

shortened by hydropriming, probably due to faster water uptake and earlier initiation of metabolism processes (Kaya et al., 2006). Hydropriming showed sharp improvement in both rate of germination and mean germination time under drought stress conditions. The lower mean germination time in unprimed seeds compared to hydroprimed seeds of the cultivars under all levels of water stress could be explained by more rapid water uptake in small seeds for early achievement of necessary moisture content required for germination. The results are in line with the findings of Thornton and Powell (1992) in Brassica and Srinivasan et al. (1999) in mustard, Fujikura et al. (1993) in cauliflower, Murillo-Amador et al. (2002) in cowpea and Kaya et al. (2006) in sunflower. On the other hand, GhassemiGolezani et al. (2008) found no significant difference for germination between primed and unprimed seeds of lentil; as they conducted the experiment under optimum conditions for lentil germination without imposing water stress.

Greater reduction in shoot length of unprimed seeds due to water stress compared to hydropriming was very evident $(\mathrm{P}<0.05)($ Tab. 2). The longest shoots were obtained from primed seeds of Pul-11 under all water stresses. Shoot length was severely influenced by water stress while the impact was much smaller in primed seeds com- pared to unprimed seeds. Increased water stress decreased root length at all cultivars except for $-0.3 \mathrm{MPa}$; however, this decrease was more prominent at unprimed seeds the respective cultivars. Although root length was adversely affected by water stresses, significant and higher enhancement due to hydropriming was very evident. Primed seeds gave the longest roots at all types of water stresses (Tab. 3).

Okçu et al. (2005) reports that root and shoot growth of pea significantly decreased by water stress at- $0.6 \mathrm{MPa}$ and above induced by PEG 6000. Murillo-Amador et al. (2002) found that seedling growth of cowpea was inhibited by PEG. The beneficial effect of hydropriming has been determined by several researchers. Sung and Chiu (1995) proposed that emergence force and seedling growth were strengthened by hydropriming in watermelon. Similarly Sadeghian and Yavari (2004) found that seedling growth severely diminished with increased drought stress irrespective of the genetic differences in sugar beet.

Depending on the decrease in shoot and root length, seedling fresh weight gradually declined with the decreasing water stress (Tab. 3). Higher seedling fresh weights were recorded from hydropriming compared to unprimed seeds at- $0.3 \mathrm{MPa}$ and above. Seedling dry weight showed a trend similar to that of fresh weight and depending on

Tab. 3. Root length $(\mathrm{cm})$, seedling fresh and dry weight $\left(\mathrm{mg} \mathrm{plant}^{-1}\right)$ of lentil cultivars exposed to hydropriming at various water stress levels

\begin{tabular}{|c|c|c|c|c|c|c|c|}
\hline \multirow{2}{*}{ Cultivar } & \multirow{2}{*}{ Water stress $(\mathrm{MPa})$} & \multicolumn{2}{|c|}{ Root length } & \multicolumn{2}{|c|}{ Seedling fresh weight } & \multicolumn{2}{|c|}{ Seedling dry weight } \\
\hline & & Unprimed & Primed & Unprimed & Primed & Unprimed & Primed \\
\hline \multirow{3}{*}{ 'Pul 11' } & 0.0 & 2.3 & 9.4 & $270^{d}$ & $323^{c}$ & $12.8^{\mathrm{cd}}$ & $21.3^{\mathrm{a}}$ \\
\hline & -0.3 & 5.3 & 9.7 & $70^{\mathrm{h}}$ & $130^{\mathrm{f}}$ & $10.3^{\mathrm{ef}}$ & $14.3^{c}$ \\
\hline & -0.6 & 3.2 & 5.0 & $21^{\operatorname{lm}}$ & $41^{\mathrm{jk}}$ & $5.3^{\mathrm{h}}$ & $7.0^{\mathrm{g}}$ \\
\hline \multirow{3}{*}{ ‘Meyveci 2001’ } & 0.0 & 3.1 & 8.3 & $372^{a}$ & $348^{b}$ & $18.8^{\mathrm{b}}$ & $22.0^{a}$ \\
\hline & -0.3 & 5.1 & 9.2 & $65^{\mathrm{hi}}$ & $116^{\mathrm{fg}}$ & $9.8^{\mathrm{cf}}$ & $13.5^{\mathrm{c}}$ \\
\hline & -0.6 & 2.8 & 4.3 & $18^{\mathrm{lm}}$ & $29^{\mathrm{kl}}$ & $4.8^{\mathrm{h}}$ & $5.0^{\mathrm{h}}$ \\
\hline \multirow{3}{*}{ 'Sultan 1' } & 0.0 & 1.3 & 7.5 & $247^{\mathrm{c}}$ & $315^{c}$ & $11.5^{\mathrm{dc}}$ & $19.5^{b}$ \\
\hline & -0.3 & 3.4 & 8.6 & $52^{\mathrm{ij}}$ & $106^{\mathrm{g}}$ & $6.5^{\mathrm{fg}}$ & $11.5^{\mathrm{de}}$ \\
\hline & -0.6 & 0.7 & 2.2 & $8^{\mathrm{m}}$ & $14^{\mathrm{lm}}$ & $2.3^{\mathrm{i}}$ & $2.3^{\mathrm{i}}$ \\
\hline
\end{tabular}


106

the decline in seedling fresh weight, dry weight decreased with water stress decreasing. Hydropriming caused higher increase in dry weight of cv. 'Sultan 1' at each water stress, but cv. 'Pul 11' produced a higher seedling dry weight. Our results agree with those given by Okçu et al. (2005), who observed that seedling fresh and dry weight of pea cultivars was severely diminished by water stress. Moreover, distinct genetic differences were found among the cultivars with respect to seedling growth subjected to water stress. Our results confirm the findings of KhajehHosseini et al. (2003) in soybean and those of MurilloAmador et al. (2002) in cowpea.

\section{Conclusions}

In many spring sown legume varieties, germination and subsequent seedling growth can be inhibited by various environmental and genetic factors depending on species and varieties. Priming may be helpful in reducing the risk of poor stand establishment under drought and permit more uniform growth under conditions of irregular rainfall. Furthermore, hydropriming is the simplest approach to hydrating seeds and minimizes the use of chemicals. Here, the beneficial effects of hydropriming in lentil seeds under water stress conditions were clearly observed. Hydroprimed seeds germinated and grew more rapidly under water stress, showing that they could be preferred for aching uniform stand establishment on drought conditions due to irregular rainfall. In addition these effects should improve seedling growth.

\section{Acknowledgements}

Help extended by Prof. Dr. Sebahattin ÖZCAN, Department of Field Crops, University of Ankara, Turkey during the study is acknowledged.

\section{References}

Angadi, S. V. and M. H. Entz (2002). Water relations of standard height and dwarf sunflower cultivars. Crop Sci. 42:152159.

Bradford, K. J. (1986). Manipulation of seed water relations via osmotic priming to improve germination under stress conditions. Hort. Sci. 21:1105-1112.

Ellis, R. H. and E. H. Roberts (1980). Seed Production, p. $605-$ 635. In: Towards a rational basis for testing seed quality. Hebblethwaite, P. D. (Eds.). Butterworths, London.

Fujikura, Y., H. L. Kraak, A. S. Basra and C. M. Karssen (1993). Hydropriming, a simple and inexpensive priming method. Seed Sci. Technol. 21:639-642.

Ghassemi-Golezani, K., A. A. Aliloo, M. Valizadeh and M. Moghaddam (2008). Effects of hydro and osmo-priming on seed germination and field emergence of lentil (Lens culinaris Medik.). Notulae Botanicae Horti Agrobotanici Cluj-Napoca 36(1):29-33.
Heydecker, W. and P. Coolbaer (1977). Seed treatments for improved performance survey and attempted prognosis. Seed Sci. Technol. 5:353-425.

Kaya, M. D., G. Okçu, M. Atak, Y. Çıkılı and Ö. Kolsarıcı (2006). Seed treatments to overcome salt and drought stress during germination in sunflower (Helianthus annuus L.). Europ. J. Agron. 24(4):291-295.

Khajeh-Hosseini, M., A. A. Powell and I. J. Bingham (2003). The interaction between salinity stress and seed vigour during germination of soybean seeds. Seed Sci. Technol. 31:715-725.

Michel, B.E. and M. R. Kaufmann (1973). The osmotic potential of polyethylene glycol 6000. Plant Physiol. 51:914-916.

Muehlbauer, F. J., J. I. Cubero and R. J. Summerfield (1985). Grain Legume Crops. p. 266-311. In: Lentil (Lens culinaris Medic.). Summerfield R. J. and E. H. Roberts (Eds.). Collins, 8 Grafton Street, London, UK.

Murillo-Amador, B., R. Lopez-Aguilar, C. Kaya, J. LarrinagaMayoral and A. Flores-Hernandez (2002). Comparative effects of $\mathrm{NaCl}$ and polyethylene glycol on germination, emergence and seedling growth of cowpea. J. Agron. Crop Sci. 188:235-247.

Mwale,S.S., C.Hamusimbiand K. Mwansa(2003).Germination, emergence and growth of sunflower (Helianthus annuus L.) in response to osmotic seed priming. Seed Sci. Technol. 31:199-206.

Parera, C. A. and D. J. Cantliffe (1994). Presowing seed priming. Hort. Rev. 16:109-141.

Okçu, G., M. D. Kaya and M. Atak (2005). Effects of salt and drought stresses on germination and seedling growth of pea (Pisum sativum L.). Turk. J. Agric. For. 29:237-242.

Sadeghian, S. Y. and N. Yavari (2004). Effect of water-deficit stress on germination and early seedling growth in sugar beet. J. Agron. Crop Sci. 190:138-144.

Sharma, S. N. and R. Prasad (1984). Effect of soil moisture regimes on the yield and water use of lentil (Lens culinaris Medic). Irrig. Sci. 5:285-293.

Singh, B. G. (1995). Effect of hydration-dehydration seed treatments on vigour and yield of sunflower. Indian J. Plant Physiol. 38:66-68.

Srinivasan, K., S. Saxena and B. B. Singh (1999). Osmo-and hydropriming of mustard seeds to improve vigour and some biochemical activities. Seed Sci. Technol. 27:785-793.

Sung, J. M. and K. Y. Chiu (1995). Hydration effects on seedling emergence strength of watermelon seed differing in ploidy. Plant Sci. 110:21-26.

Thornton, J. M. and A. A. Powell (1992). Short term aerated hydration for the improved of seed quality on Brassica oleracea. Seed Sci. Res. 2:41-49. 